\title{
HUBUNGAN SANITASI TEMPAT PENGGILINGAN DAGING DENGAN KUALITAS BAKTERIOLOGIS (Salmonella sp.) DAGING GILING
}

Rinda Astri Setyawati, Narwati*, Deddy Adam

Jurusan Kesehatan Lingkungan Poltekkes Kemenkes Surabaya

*Email korespondensi: narwatisuprapto@gmail.com

\begin{abstract}
ABSTRAK
Daging giling merupakan jenis bahan pangan yang mudah rusak (perishablefood). Kerusakan dapat disebabkan oleh bakteri Salmonella melalui faktor sanitasi tempat diantaranya lokasi, bangunan, tata ruang dan fasilitas sanitasi. Faktor sanitasi tempat penggilingan daging di Pasar Tambah Rejo yang tidak memenuhi syarat berdasarkan Perka BPOM No. 5 Tahun 2015 berpotensi menyebabkan kontaminasi. Tujuan penelitian ini adalah untuk mengetahui hubungan sanitasi tempat penggilingan daging dengan kualitas bakteriologis (Salmonella sp.) daging giling di Pasar Tambah Rejo Surabaya Tahun 2020.

Desain penelitian merupakan penelitian analitik dengan pendekatan cross sectional. Populasi dalam penelitian ini adalah lokasi tempat penggilingan daging Pasar Tambah Rejo Surabaya sejumlah 6 dan air bersih di tempat penggilingan daging Pasar Tambah Rejo Surabaya sejumlah 1 . Besar sampel ditentukan dengan menggunakan teknik total sampling. Metode pengumpulan data dengan cara observasi dan uji laboratorium. Analisis data menggunakan uji korelasi spearman rank.

Hasil penelitian diperoleh 5 lokasi tempat penggilingan daging kurang memenuhi syarat, 4 bangunan kurang memenuhi syarat, 2 tata ruang kurang memenuhi syarat, 5 fasilitas sanitasi cukup memenuhi syarat. Uji hipotesis menunjukkan bahwa ada hubungan antara sanitasi tempat penggilingan daging dengan kualitas bakteriologis (Salmonella sp.) pada daging giling di Pasar Tambah Rejo Surabaya tahun 2020 (P < 0.05).

Disarankan pekerja membersihkan lantai dengan cara mengepel menggunakan cairan desinfektan, PD Pasar Surya dapat merealisasikan program perbaikan saluran pembuangan yang terbuka dengan memberi penutup berupa penutup dari bahan besi.
\end{abstract}

Kata kunci : Fasilitas sanitasi, daging giling, Salmonella sp.

\section{PENDAHULUAN}

Daging merupakan kategori bahan pangan yang mudah rusak (perishable food) (Yaman, 2019). Daging mengandung enzim yang dapat menguraikan protein dan lemak sehingga menyebabkan daging mengalami pembusukan. Pembusukan daging dapat disebabkan oleh mikroorganisme dan berpotensi menyebabkan foodborne disease.

Foodborne disease terjadi melalui 2 (dua) cara yaitu infeksi dan intoksikasi (Suardana dan Swacita, 2009). Infeksi makanan dapat disebabkan oleh bakteri Salmonella dan menyebabkan penyakit Salmonellosis. Peraturan Kepala Badan Pengawas Obat dan Makanan No. 16 Tahun 2016 menyebutkan kriteria mikrobiologi dalam pangan olahan dengan indikator bakteri Salmonella pada daging dan produk olahan daging adalah negatif/25 gram.

Tercatat terdapat 24 kasus $(77,42 \%)$ kasus keracunan makanan di Indonesia pada bulan April-Juni 2017 disebabkan oleh makanan (BPOM, 2017). Untuk mencegah terjadinya keracunan makanan, maka sebaiknya bahan pangan harus diolah dengan benar dan memenuhi persyaratan dalam Peraturan Kepala BPOM No. 5 Tahun 2015 tentang pedoman cara ritel pangan yang baik di pasar tradisional.

Penyebab kontaminasi makanan dapat terjadi melalui faktor lokasi bangunan. Penelitian Amalia et al. (2019) menyatakan bahwa terdapat hubungan sanitasi tempat pengolahan makanan dengan kontaminasi bakteri ditinjau dari lokasi bangunan. Faktor lain yang dapat 
menyebabkan kontaminasi bakteri pada makanan adalah bangunan. Penelitian Suci dan Suyasa (2018) menyebutkan bahwa terdapat 32 (74\%) tempat pengolahan makanan tidak memenuhi syarat yang ditinjau dari keadaan bangunan yang kotor dan berpotensi menyebabkan kontaminasi. Selain bangunan, tata ruang merupakan salah satu faktor penting dalam proses pengolahan makanan. Penelitian oleh Yunita (2013) menyebutkan bahwa tata ruang bangunan terpisah antara ruang produksi lain untuk menghindari terjadinya kontaminasi silang. Faktor lain yang dapat menyebabkan kontaminasi yaitu fasilitas sanitasi. Penelitian oleh Yunus (2015) tentang hubungan fasilitas sanitasi dengan kontaminasi bakteri E.coli pada makanan menunjukkan bahwa terdapat $6(50 \%)$ dari 12 rumah makan memiliki pengelolaan sampah yang tidak baik menyebabkan kontaminasi E.coll pada makanan. Selain itu, alat alat penggilingan daging juga dapat menyebabkan kontaminasi bakteri pada daging giling. Penelitian oleh Sutoko et al. (2019) menyebutkan bahwa pada alat penggilingan daging terdapat $30 \mathrm{CFU} / \mathrm{cm}^{2}$ jumlah koloni. Survey pendahuluan di Pasar Tambah Rejo Surabaya pada bulan September tahun 2019, didapatkan informasi bahwa Pasar Tambah Rejo memiliki 6 jasa penggilingan daging. berdasarkan observasi pada lokasi bangunan, ditunjukkan bahwa lokasi tempat penggilingan daging berdekatan dengan kandang ayam dan tempat pembuangan sampah sementara (TPS). Kondisi lantai kotor dan tergenang oleh air.

Tujuan penelitian ini untuk mengetahui hubungan sanitasi tempat penggilingan daging dengan kualitas bakteriologis (Salmonella $s p$.) daging giling di Pasar Tambah Rejo Surabaya Tahun 2020.

\section{METODE PENELITIAN}

Desain penelitian ini adalah penelitian analitik dengan pendekatan cross sectional. Populasi dalam penelitian yaitu lokasi tempat penggilingan daging di Pasar Tambah Rejo Surabaya sejumlah 6 dan air bersih di tempat penggilingan daging Pasar Tambah Rejo Surabaya sejumlah 1. Teknik pengambilan sampel yang digunakan adalah total sampling dimana seluruh populasi dijadikan sampel. Variabel yang diteliti meliputi variabel bebas yaitu sanitasi tempat penggilingan daging dan variabel terikat yaitu kualitas bakteriologis (Salmonella $s p$.) daging giling. Analisis data menggunakan uji korelasi spearman rank yaitu untuk mengukur hubungan antara dua variabel yang berskala ordinal.

\section{HASIL DAN PEMBAHASAN}

Tabel 1

DISTRIBUSI PENILAIAN LOKASI TEMPAT PENGGILINGAN DAGING DI PASAR

TAMBAH REJO SURABAYA TAHUN 2020 No. Lokasi Frekuensi Persentase

\begin{tabular}{lccc}
\hline 1. & Baik & 0 & $\mathbf{( \% )}$ \\
\hline 2. & Cukup & 1 & $0 \%$ \\
\hline 3. & Kurang & 5 & $83 \%$ \\
\hline & Jumlah & 6 & $100 \%$ \\
\hline
\end{tabular}

Berdasarkan Tabel 1 dapat diketahui bahwa sebagian besar lokassi penggilinan padi adalah kurang yaitu sebesar $83 \%$ (lokasi). Aspek yang dinilai berdasarkan Peraturan Kepala BPOM No. 5 Tahun 2015 tentang Pedoman Cara Ritel Pangan yang Baik di Pasar Tradisional yakni tidak berdekatan dengan tempat sampah. Pada kenyataannya, masih terdapat lokasi tempat penggilingan daging di Pasar Tambah Rejo yang berdekatan dengan tempat sampah. Kondisi ini menyebabkan serangga dan binatang pengganggu yang berasal dari tempat sampah tidak tertutup hinggap pada makan disekitarnya dan berpotensi membawa agent penyakit. Sejalan dengan penelitian Sawong et al. (2016) dijelaskan bahwa kontaminasi bakteri yang ditimbulkan oleh sampah dapat terjadi apabila tempat pembuangan sampah tidak tertutup sehingga menyebabkan lalat berkeliaran di sekitar tempat sampah dan apabila hinggap pada makanan berpotensi dapat menyebabkan kontaminasi. Pesyaratan lain pada lokasi yaitu tidak berdekatan dengan saluran pembuangan, bebas dari bau, kotoran, debu dan asap. Akan tetapi, masih 
terdapat tempat penggilingan daging yang berdekatan dengan saluran pembuangan. Penelitian oleh Yuniatun et al. (2019) menyebutkan bahwa lokasi pengolahan makanan yang berpotensi menyebabkan kontaminasi adala lokasi yang dekat dengan sumber pencemar.

\section{Tabel 2}

DISTRIBUSI PENILAIAN BANGUNAN

TEMPAT PENGGILINGAN DAGING DI PASAR TAMBAH REJO SURABAYA TAHUN 2020

\begin{tabular}{|c|c|c|c|}
\hline No. & bangunan & frekuensi & $\begin{array}{c}\text { Persentase } \\
(\%)\end{array}$ \\
\hline 1. & Baik & 0 & $0 \%$ \\
\hline 2. & Cukup & 2 & $33 \%$ \\
\hline \multirow[t]{2}{*}{3.} & Kurang & 4 & $67 \%$ \\
\hline & Jumlah & 6 & $100 \%$ \\
\hline
\end{tabular}

Berdasarkan Tabel 2 dapat diketahui bahwa sebagian besar bangunan tempat penggilingan daging memiliki bangunan berkriteriakurang yaitu sebesar $67 \%$ (4 bangunan). Aspek yang dinilai berdasarkan Peraturan Kepala BPOM No. 5 Tahun 2015 meliputi lantai, dinding dan atap. Persyaratan lantai yakni kedap air, memiliki permukaan yang rata, tidak licin, tidak retak dan mudah dibersihkan. Namun, masih terdapat lantai di tempat penggilingan daging yang memiliki lantai tidak kedap air. Selain lantai, persyaratan bangunan yang lain adalah pada dinding. Berdasarkan observasi yang dilakukan oleh peneliti di tempat penggilingan daging, masih terdapat tempat penggilingan daging yang memiliki dinding tidak kedap air. Dinding yang tidak kedap air akan sulit untuk dibersihkan sehingga mengakibatkan dinding menjadi kotor dan lembab.

Berdasarkan Kepmenkes No. 519/MENKES/SK/VI/2008 persyaratan atap yaitu tidak bocor, kuat, dan tidak menjadi tempat berkembang biaknya binatang penular penyakit. Dalam penelitian ini masih terdapat atap di tempat penggilingan yang bocor. Kebocoran atap ini terjadi di musim hujan yang akan menyebabkan air masuk ke tempat penggilingan daging sehingga tempat tersebut tergenang air dan becek serta tempat penggilingan daging yang telah rapuh. Tikus dan kecoa akan mudah masuk ke tempat penggilingan daging melalui atap yang rapuh.

Tabel 3

DISTRIBUSI PENILAIAN TATA RUANG

TEMPAT PENGGILINGAN DAGING DI PASAR TAMBAH REJO SURABAYA TAHUN 2020

\begin{tabular}{lccc}
\hline No. & $\begin{array}{c}\text { Tata } \\
\text { ruang }\end{array}$ & frekuensi & $\begin{array}{c}\text { Persentase } \\
(\%)\end{array}$ \\
\hline 1. & Baik & 2 & $33,3 \%$ \\
\hline 2. & Cukup & 2 & $33,3 \%$ \\
\hline 3. & Kurang & 2 & $33,3 \%$ \\
\hline & Jumlah & 6 & $100 \%$ \\
\hline
\end{tabular}

Berdasarkan Tabel 3 dapat diketahui bahwa tata ruang tempat penggilingan daging di Pasar tambah Rejo adalah baik, cukup dan kurang mempunyai persentase yang sama yaitu $33.3 \%$. Observasi mengenai tata ruang tempat penggilingan daging di Pasar Tambah Rejo Surabaya mendapatkan hasil mendapatkan hasil bahwa terdapat beberapa komponen penilaian yang tidak memenuhi persyaratan berdasarkan Peraturan Kepala BPOM No. 05 Tahun 2015. Pembagian area telah sesuai dengan jenis komoditi sehingga hal ini akan meminimalisir terjadinya kontaminasi silang antar komoditi satu dengan yang lain. Namun, masih terdapat tempat penggilingan daging yang berdekatan dengan sumber pencemar yaitu tempat pemotongan unggas dan tempat penampungan sampah sementara. Tempat penggilingan daging di Pasar Tambah Rejo berdekatan dengan tempat pemotogan unggas menyebabkan lalat yang berasal dari tempat pemotongan unggas berkeliaran di tempat penggilingan daging. Lalat yang berasal dari tempat pemotongan unggas berpotensi untuk membawa bakteri Salmonella karena mengingat bakteri Salmonella memiliki habitat di usus halus hewan (SNI, 2009). 
Tabel 4

DISTRIBUSI PENILAIAN FASILITAS

SANITASI TEMPAT PENGGILINGAN

DAGING DI PASAR TAMBAH REJO

SURABAYA TAHUN 2020

\begin{tabular}{lccc}
\hline No. & $\begin{array}{c}\text { Fasilitas } \\
\text { Sanitasi }\end{array}$ & $\begin{array}{c}\text { Frekuensi Persentase } \\
(\%)\end{array}$ \\
\hline 1. & Baik & 1 & $17 \%$ \\
\hline 2. & Cukup & 5 & $83 \%$ \\
\hline 3. & Kurang & 0 & $0 \%$ \\
\hline & Jumlah & 6 & $100 \%$ \\
\hline
\end{tabular}

Berdasarkan Tabel 4 dapat diketahui bahwa sebagian besar fasilitas sanitasi tempat penggilingan daging memiliki fasilitas sanitasi adalah cukup sebesar 83\% (5 fasilitas sanitasi). Aspek yang dinilai pada fasilitas sanitasi yaitu air bersih. Air di tempat penggilingan daging telah memenuhi persyaratan kuantitas air bersih ditunjukkan dengan air mengalir dengan lancar. Disisi kualitas bakteriologis, air bersih di tempat penggilingan daging ini telah memenuhi persyaratan dengan kandungan coliform $46 \mathrm{CFU} / 100 \mathrm{ml}$. Kualitas bakteriologis air bersih ini mengindikasikan telah terpenuhinya persyaratan kualitas air berdasarkan Peraturan Menteri Kesehatan No. 32 Tahun 2017 tentang Standar Baku Mutu Kesehatan Lingkungan dan Persyaratan Kesehatan Air untuk Keperluan Higiene Sanitasi, Kolam Renang, Solus Per Aqua, dan Pemandian Umum.

Sarana pencuci tangan dalam penelitian ini diketahui masih terdapat tempat penggilingan daging tidak memiliki sabun cuci tangan pada sarana pencuci tangan. Pekerja masih mencuci tangan menggunakan air yang ditampung dalam bak tanpa menggunakan sabun serta tidak dilengkapi dengan lap yang bersih guna mengeringkan tangan.

Tempat pembuangan sampah di tempat penggilingan daging dijumpai masih dalam kondisi tidak tertutup. Tempat sampah yang tidak tertutup berpotensi menjadi tempat perindukan lalat, kecoa dan tikus berkeliaran di tempat sampah. Pekerja di tempat penggilingan daging membuang sampah ketika tempat sampah sudah benar-benar penuh dalam waktu 2 hari. Hal ini tidak memenuhi persyaratan yang seharusnya sampah dibuang dalam waktu 1x dalam sehari.

Berdasarkan Tabel 5 dapat diketahui bahwa terdapat 2 tempat penggilingan yang daging gilingnya mengandung bakteri Salmonella dan 4 negatif mengandung bakteri Salmonella. Peraturan Kepala Badan Pengawas Obat dan Makanan No. 16 Tahun 2016 menyebutkan kriteria mikrobiologi dalam pangan olahan dengan indikator bakteri Salmonella pada daging dan produk olahan daging adalah negatif per 25 gram. Hal ini berarti beberapa daging giling di Pasar Tambah Rejo Surabaya belum memenuhi persyaratan.

Bakteri Salmonella masuk ke dalam tubuh manusia melalui pangan yang tercemar. Bakteri yang tumbuh pada suhu $15^{\circ} \mathrm{C}-41^{\circ} \mathrm{C}$ ini dapat mengontaminasi pangan melalui beberapa faktor diantaranya yaitu sanitasi tempat. Sejalan dengan penelitian Wasisto et al. (2017) menunjukkan bahwa terdapat $8(47 \%)$ bahan makanan terkontaminasi bakteri Salmonella $s p$. karena memiliki sanitasi tempat yang tidak baik. Keberadaan bakteri Salmonella pada makanan apabila tertelan oleh tubuh manusia dapat menyebabkan penyakit Salmonellosis yang memiliki gejala berupa sakit perut, diare, rasa mual, kedinginan, demam dan sakit kepala.

\section{Tabel 5}

HASIL PEMERIKSAAN KANDUNGAN SALMONELLA PADA DAGING GILING DI PASAR TAMBAH REJO SURABAYA TAHUN 2020

\begin{tabular}{cccc}
\hline No. & $\begin{array}{c}\text { Tempat } \\
\text { Penggilingan }\end{array}$ & $\begin{array}{c}\text { Kandungan Keterangan } \\
\text { Salmonella }\end{array}$ & \\
\hline 1. & $\mathrm{~A}$ & Negatif & $\mathrm{MS}$ \\
\hline 2. & $\mathrm{~B}$ & Negatif & $\mathrm{MS}$ \\
\hline 3. & $\mathrm{C}$ & Positif & $\mathrm{TMS}$ \\
\hline 4. & $\mathrm{D}$ & Positif & $\mathrm{TMS}$ \\
\hline 5. & $\mathrm{E}$ & Negatif & $\mathrm{MS}$ \\
\hline 6. & $\mathrm{~F}$ & Negatif & $\mathrm{MS}$ \\
\hline
\end{tabular}


Tabel 6

DISTRIBUSI PENILAIAN SANITASI

TEMPAT PENGGILINGAN DAGING DI PASAR TAMBAH REJO SURABAYA TAHUN 2020

\begin{tabular}{lccc}
\hline No. & $\begin{array}{l}\text { Sanitasi Frekuensi } \\
\text { Tempat }\end{array}$ & $\begin{array}{c}\text { Persentase } \\
(\%)\end{array}$ \\
\hline 1. & Baik & 1 & $17 \%$ \\
2. & Cukup & 3 & $50 \%$ \\
3. & Kurang & 2 & $33 \%$ \\
\hline & Jumlah & 6 & $100 \%$ \\
\hline
\end{tabular}

Berdasarkan Tabel 6 dapat diketahui bahwa sebagian besar tempat penggilingan daging mempunyai sanitasi tempat yang cukup yaitu sebesar $50 \%$ (3 tempat) dan 33\% (2 tempat) sanitasi tempatnya kurang. Berdasarkan hasil observasi, terdapat komponen penilaian pada sanitasi tempat yang belum memenuhi syarat sesuai dengan Peraturan Kepala BPOM No. 05 Tahun
2015. Kondisi tempat penggilingan daging di Pasar Tambah Rejo Surabaya yang berdekatan dengan sumber pencemar yaitu tempat sampah dan saluran pembuangan menyebabkan terjadinya kontaminasi bakteri pada daging giling. Hal ini terjadi apabila serangga dan binatang pengganggu yang berasal dari tempat sampah tidak tertutup dapat membawa bakteri kemudian hinggap pada daging giling, sehingga daging giling terkontaminasi. Sejalan dengan penelitian Sawong et al. (2016) yang menyebutkan kontaminasi bakteri karena sampah dapat terjadi apabila tempat pembuangan sampah tidak ditutup sehingga menyebabkan lalat berkeliaran di sekitar tempat sampah dan hinggap pada sampah, sehingga apabila lalat hinggap pada makanan akan menyebabkan kontaminasi makanan.

Tabel 7

ANALISIS BIVARIAT SANITASI TEMPAT PENGGILINGAN DAGING DENGAN KUALITAS BAKTERIOLOGIS ( SALMONELLA SP.) PADA DAGING GILING DI PASAR TAMBAH REJO SURABAYA TAHUN 2020

\begin{tabular}{lccccc}
\hline No. & $\begin{array}{l}\text { Sanitasi } \\
\text { Tempat }\end{array}$ & \multicolumn{2}{l}{$\begin{array}{l}\text { Kualitas Bakteriologis } \\
\text { (Salmonella sp.) Daging } \\
\text { Giling }\end{array}$} & P value \\
& MS & \multicolumn{2}{c}{ TMS } & \\
\hline 1. & Baik & $1(100 \%)$ & $0(0,0 \%)$ & $1(100 \%)$ & \\
\hline 2. & Cukup & $3(100 \%)$ & $0(0,0 \%)$ & $3(100 \%)$ & 0,016 \\
\hline 3. & Kurang & $0(0,0 \%)$ & $2(100 \%)$ & $2(100 \%)$ & \\
\hline
\end{tabular}

Berdasarkan Tabel 7 dapat diketahui bahwa terdapat 1 tempat penggilingan daging memiliki sanitasi yang berkriteria baik tidak mengandung bakteri Salmonella, terdapat 3 tempat penggilingan daging memiliki sanitasi yang berkriteria cukup tidak mengandung bakteri Salmonella, dan terdapat 2 tempat penggilingan daging memiliki sanitasi yang berkriteria kurang mengandung bakteri Salmonella. Analisis bivariat menggunakan uji korelasi spearman rank mendapat hasil p value $(0,016)<(0,05)$ yang berarti ada hubungan antara sanitasi tempat penggilingan daging terhadap kualitas bakteriologis (Salmonella $s p$.) pada daging giling.

Berdasarkan observasi yang peneliti lakukan, hal ini terjadi karena terdapat komponen penilaian pada sanitasi tempat yang belum memenuhi syarat sesuai dengan Peraturan Kepala BPOM No. 05 Tahun 2015. Terdapat lokasi tempat penggilingan daging yang belum memenuhi persyaratan. Kondisi tempat penggilingan daging di Pasar Tambah Rejo Surabaya yang berdekatan dengan sumber pencemar yaitu tempat sampah dan saluran pembuangan menyebabkan terjadinya kontaminasi bakteri pada daging giling. Sejalan dengan penelitian Sawong et al. (2016) yang menyebutkan kontaminasi bakteri karena sampah dapat terjadi apabila tempat pembuangan sampah tidak ditutup sehingga menyebabkan lalat berkeliaran di sekitar tempat sampah dan hinggap pada sampah, sehingga apabila lalat hinggap 
pada makanan akan menyebabkan kontaminasi makanan.

Faktor lain yang menyebabkan terjadinya kontaminasi bakteri Salmonella pada daging giling yaitu bangunan. Penelitian Suyasa (2018) menyebutkan bahwa terdapat 32 (74\%) tempat pengolahan makanan tidak memenuhi syarat dilihat dari keadaan bangunan yang kotor berpotensi menyebabkan kontaminasi. Selain bangunan, tata ruang juga menjadi faktor terjadinya kontaminasi bakteri pada daging giling. Jarak tempat penggilingan daging yang berdekatan dengan sumber pencemar yaitu saluran pembuangan dan tempat pemotongan unggas menyebabkan terjadinya kontaminasi bakteri. Sejalan dengan penelitian Penelitian oleh Yuniatun et al. (2019) lokasi pengolahan makanan yang berpotensi menyebabkan kontaminasi adalah lokasi yang dekat dengan sumber pencemar.

Fasilitas sanitasi juga merupakan faktor terjadinya kontaminasi bakteri Salmonella pada daging giling. Aspek yang dinilai pada fasilitas sanitasi yaitu air bersih. Keberadaan bakteri coliform pada air bersih menjadi indikator air bersih. Menurut penelitian oleh Yulianto et al. (2017) air yang tidak bersih dapat mengontaminasi makanan pada saat proses pengolahan. Selain air bersih, aspek penilaian pada fasilitas sanitasi yaitu sarana pencuci tangan. Seluruh tempat penggilingan daging di Pasar Tambah Rejo tidak memiliki petunjuk mencuci tangan. Tidak terdapat lap untuk mengeringkan tangan dan sebagian tempat penggilingan daging yang memiliki lap tidak menggantinya apabila telah kotor. Hal ini dapat menyebabkan terjadinya kontaminasi ulang. Sejalan dengan penelitian Sahani (2019) yang menyebutkan bahwa lap tangan yang kotor rentan terhadap kontaminasi bakteri. Tempat pembuangan sampah juga menjadi aspek penilaian pada fasilitas sanitasi. Masih ada tempat penggilingan daging yang memiliki tempat sampah tidak tertutup. Tempat sampah yang tidak tertutup menyebabkan lalat berkeliaran di tempat sampah. Sejalan dengan penelitian Oktaviani (2019) menyebutkan bahwa tempat sampah yang tidak tertutup penutup akan mengundang serangga terutama lalat. Sehingga apabila lalat hinggap pada daging giling akan menyebabkan terjadinya kontaminasi bakteri.

\section{KESIMPULAN}

Terdapat hubungan sanitasi tempat penggilingan daging dengan kualitas bakteriologis (Salmonella sp.) pada daging giling di Pasar Tambah Rejo Surabaya tahun 2020

\section{SARAN}

Disediakan lap bersih pada sarana pencuci tangan dan segera mengganti apabila telah kotor, serta dilakukan penelitian lanjutan terhadap faktor lain yang berpotensi mengontaminasi makanan seperti pada peralatan penggilingan dan personal hygiene pekerja di tempat penggilingan.

\section{DAFTAR PUSTAKA}

Amalia, Suci F., Hestiningsih, R., Ginandjar, P., Wuryanto A.M. 2019. Faktor-faktor yang Mempengaruhi Kualitas Mikrobiologis Jajanan Batagor di Kecamatan Tembalang. Jurnal Kesehatan Masyarakat Vol. 7

BPOM. 2017. Berita Keracunan Bulan April-Juni 2017. (ik.pom.go.id) diakses 4 November 2019.

Oktaviani F. 2019. Perilaku Pedagang dalam Penerapan Personal Hygiene dan Kualitas Bakteriologis Makanan Jajanan serta Air Bersih di Pasar Tambak Rejo Surabaya. Karya Tulis Ilmiah. Poltekkes Kemenkes Surabaya.

Peraturan Kepala Badan Pengawas Obat dan Makanan Nomor 5 Tahun 2015 tentang Cara Ritel Pangan yang Baik di Pasar Tradisional.

Peraturan Menteri Kesehatan No. 32 tahun 2017 tentang Standar Baku Mutu Kesehatan Lingkungan dan Persyaratan Kesehatan Air untuk Keperluan Higiene Sanitasi, Kolam Renang, Solus Per Aqua, dan Pemandian Umum.

Sahani W. dan Nasir I.R. 2019. Analisis Kondisi Sanitasi dengan Keberadaan Bakteri Coliform pada Daging Sapi di Pasar Terong Kota 
Makassar. Jurnal Sulolipu Vol. 19 No. 1.

Sawong, K., Andrias D., Muniroh L. 2016. Penerapan Higiene Sanitasi Jasaboga pada Katering Golongan A2 dan Golongan A3 di Kota Palangkaraya Provinsi Kalimantan Tengah. Jurnal Media Gizi Indonesia Vol.11 No. 1.

SNI 7388:2009 tentang Batas Maksimum Cemaran Mikroba dalam Pangan.

Suci I.G.A.A., Suyasa I. N. G. 2017.Keadaan Hygiene Sanitasi Pemindangan Ikan Desa Kusamba Kecamatan Dawan Kabupaten Klungkung Tahun 2017. Jurnal Kesehatan Lingkungan Vol. 8

Suardana I.W, Swacita I.B.N. 2009. Higiene Makanan. Denpasar : Udayana University Press.

Sutoko A., Hapsari R., Hadi P. 2019. Kualitas Bakteriologi Peralatan Masak dan Makan di Rumah Sakit Nasional Diponegoro. Jurnal Kedokteran Diponegoro Vol. 8

Yaman, M. Aman. 2019. Teknologi Penanganan dan Pengolahan Limbah dan Hasil Samping Peternakan. Google Books : Syiah Kuala University Press.
Yulianto, Rochmawati, Selviana. 2017. Studi Praktik Higiene Penjamah dan Keberadaan Kuman Coliform pada Cincau Hitam Kota Pontianak. Jurnal Mahasiswa dan Penelitian Kesehatan.

Yunita. 2013. Studi Penerapan Cara Produksi Makanan yang Baik pada Jajanan Bakso yang Dikonsumsi Murid di SDN Kompleks Mangkura Kota Makassar. Jurnal MKMI Hal 153-161.

Yunus, Salma P., Umboh J.M.L., Pinontoan O. 2015. Hubungan Personal Higiene dan Fasilitas Sanitasi dengan Kontaminasi Escherichia coli pada Makanan di Rumah Makan Padang Kota Manado dan Kota Bitung. Jurnal Kesehatan Masyarakat Vol. 5,

Wasisto, B.H., Martini, Yuliawati S., Purwantisari. 2017. Gambaran Sanitasi Tempat Berdagang Warung Penyet di Kecamatan Tembalang. Jurnal Kesehatan Masyarakat Vol. 5 